УДК 55(092)

\title{
К 80-летию доцента Надежды Ермолаевны Молоштановой
}

\section{Н.А. Бусыгина}

Пермский государственный национальный исследовательский университет, 614990, Пермь, ул. Букирева, 15. E-mail: mineral @psu.ru

(Статья поступила в редакицю 7 сентября 2016 г.)

Приведены сведения о научной, учебной и производственной деятельности доцента Н.Е. Молоштановой.

Ключевые слова: Молоштанова Н.Е., Пермский университет.

DOI: 10.17072/psu.geol.32.100

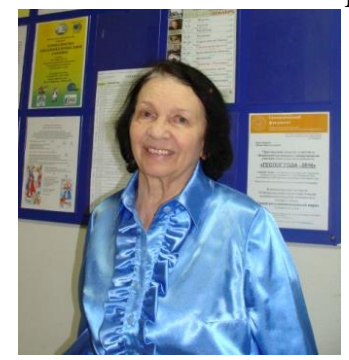

Н.Е. Молоштанова в 1968 г. была принята на должность ассистента кафедры минералогии и петрографии ПГУ.

В 1974-81 гг. она работала в Уральском филиале ВНИИГалургии, Вся дальнейшая учебно-научная деятельность Надежды Ермолаевны связана с кафедрой минералогии и петрографии ПГУ. В 1988 г. она защитила кандидатскую диссертацию «Геологические условия осадконакопления сильвинитов Верхнекамского месторождения».

Значительным вкладом в развитие кафедры явилась подготовка учебных пособий «Литология» (2006, 2013 гг.); «Петрография» (2012 г.); «Литогенез осадочных бассейнов» $(2014$ г.).

Основное направление научных исследований связано с изучением процессов формирования солей и минералоготехнологических свойств калийных руд по заказам ОАО «Сильвинит», «Уралкалий», «Батыс-Калий» (Казахстан) и ООО «ЗУМК-Инжиниринг» (Узбекистан). По результатам исследования продуктивных

пластов шахтного поля БКРУ-3 ею предложено изменение регламента рудоподготовки калийной руды. С 2011 г. является начальником отдела оптических методов исследования сектора наноминералогии ПГНИУ, где под ее руководством выполнено несколько десятков работ петрографического направления. Общее количество публикаций - более 160 . Она - почётный работник высшего профессионального образования Российской Федерации.

Она выполняла обязанности зам. декана по общественной работе, являлась членом методической комиссии геологического факультета, курировала работу юных геологов, организовывала курсы повышения квалификации для производственных организаций за рубежом.

Изучение вещественного состава и минералого-технологических свойств калийных солей Тюбегатанского месторождения позволило ей внести рекомендации по его разработке на ученом совете Министерства геологии Узбекистана.

Сотрудники кафедры сердечно поздравляют юбиляра и желают ей многих лет плодотворного сотрудничества.

\section{To the $8^{\text {th }}$ Anniversary of N.E. Moloshtanova}

\section{N.A. Busygina}

Perm State University, 15 Bukirev Str., Perm 614990, Russia

On the anniversary of teaching and scientific activity of N.E.Moloshtanova in Perm State University.

Key words: Nadezhda Moloshtanova, Perm State University. 